\section{Colleges alarmed by new plans \\ Washington}

US UNIVERSITIES are still up in arms about President Reagan's proposal to overhaul the tax system, even though the features of the original plan that caused most apprehension have been toned down. While the President is taking every opportunity to rally support for his proposal, the American Council on Education (ACE), an organization representing a wide spectrum of higher education institutions, has

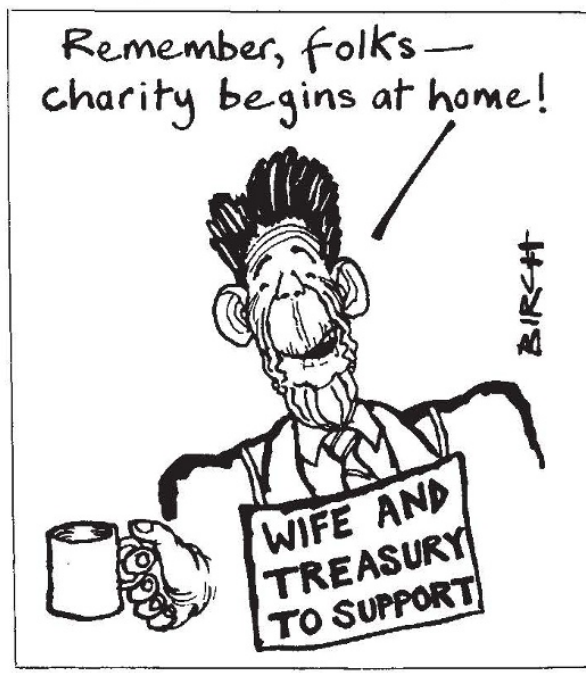

pulled out all the stops for its lobbying effort to oppose the plan in its present form.

The plan seeks to rationalize and simplify the US domestic tax system so as to avoid some of its more flagrant injustices while not changing significantly the total amount of revenue raised. One of its important elements would severely restrict the deductions against gross income that can be claimed for charitable donations, which at present allow taxpayers to decide whether to make payments to the Inland Revenue Service or to charities of their choice - a system open to abuse.

The effect of the change, according to $\mathrm{ACE}$, will be to increase substantially the cost of giving to legitimate public-service institutions such as colleges and universities, and the council fears a precipitous drop in charitable donations as a result. ACE quotes a study by Lawrence Lindsey of Harvard University which concludes that the tax plan would reduce donations to non-profit organizations by $\$ 11,000$ million, or 17 per cent. Private universities alone receive $\$ 3,000$ million a year in charitable contributions.

Under an earlier version of the taxreform plan, charitable contributions would have been deductible only if they exceeded 2 per cent of a taxpayer's gross income, and donations of non-cash items such as real estate and works of art would no longer have been deductible at their full market value. The outcry over these provisions led the President to abandon them, but ACE claims that the substitute proposals are not much better. "What they've given with one hand they've taken away with the other", says one ACE analyst.

ACE's principal worry now concerns a special tax provision called "minimum tax", to be used exclusively for wealthy people who have their tax affairs so well arranged that, without the minimum tax provision, they would pay no tax at all. Under existing tax arrangements, charitable donations are not counted in with the other deductions in calculating minimum tax, but the President's intention now is that they should be, increasing the cost of giving by the wealthy. $\mathrm{ACE}$, quoting Lindsey again, says that 65 per cent of all donations of appreciated property come from taxpayers with an adjusted gross income of more than $\$ 100,000$ who use the minimum tax provision. The effect of the proposed change would be "devastating", he says.

ACE's concern about charitable donations is not confined to wealthy givers. A
Washington

THE National Research Council is urging a major expansion of US Arctic research. In a report ${ }^{*}$ published last week, the council identifies twelve "issues of national concern" in the Arctic, and lists the most urgent research needs. A new dedicated polar research ship and a permanent logistics base near the Arctic coast are thought to be the minimum requirements.

The Arctic Research and Policy Act, signed by President Reagan in July 1984, called for a comprehensive 5-year research plan for the Arctic. The present study, under the chairmanship of Charles Bentley of the University of Wisconsin, was undertaken at the request of the committee preparing the research plan. Unlike many reports from the National Research Council, this explicitly relates scientific research to US needs in, for example, defence, weather forecasting, energy and materials, transport and communications.

Bentley's committee did not attempt to decide priorities between scientific research areas, though within each of the twelve considered, it gave rankings by importance. Thus, in near-Earth space physics, it attaches most importance to improvements in predictions of auroral, ionospheric and magnetic perturbations, which can affect communications. In atmospheric sciences, oceanography and biology, the committee attaches most importance to the value of the relatively undisturbed Arctic environment for measur- different provision in the plan that would primarily affect lower-income taxpayers would also reduce contributions to nonprofit organizations - by $\$ 6,700$ million, according to ACE's estimate. And other aspects of the reform proposal that would affect higher education have nothing to do with charity; they include a proposal that might lower state tax revenues, a proposal to tax scholarships as personal income and a restriction on the use of tax-exempt bonds issued by state and local governments that would severely restrict their use by institutions of higher education.

The future of the plan is hard to predict. Despite President Reagan's apparently firm commitment to reform, there is a marked lack of enthusiasm in Congress and indeed in the country generally, especially among those who might benefit most from the existing array of tax loopholes to suit every pocket. Speedy progress on tax reform would certainly be a feather in the cap for Congressman Dan Rostenkowski, chairman of the committee in the House of Representatives that will draft the legislation. But other demands on Congress's time, mean that the proposal is not going to get an easy ride.

Tim Beardsley

\title{
Strategy and science mix
}

ing and monitoring long-term changes, for example in atmospheric trace gases and ocean currents. Much basic ecology also remains to be described.

The report says the United States should concentrate its efforts in Alaska, giving suitable regard to the wishes of local inhabitants, but also stresses the need for international cooperation in Arctic studies. The present "fragmentary" domestic organization of Arctic research needs to be improved, with "big science" projects sharing logistical support. More satellite ground stations should be built, to receive data from both US and foreign satellites, and data should be published in the open refereed literature.

High priority should also be given to geological maps and surveying for oil and minerals, according to the report. As a practical engineering matter, there is an urgent need for better understanding of the formation and distribution of permafrost, with an observation network to monitor changes. And there should be an integrated research programme on seaice, concentrating in particular on engineering to withstand ice forces and the use of snow and ice as engineering materials. But this will require, according to the committee, better educational opportunities and incentives to encourage careers in Arctic science and engineering.

Tim Beardsley

* National Issues and Reszarch Priorities in the Arctic. Polar Research Board, National Research Council, 1985. 